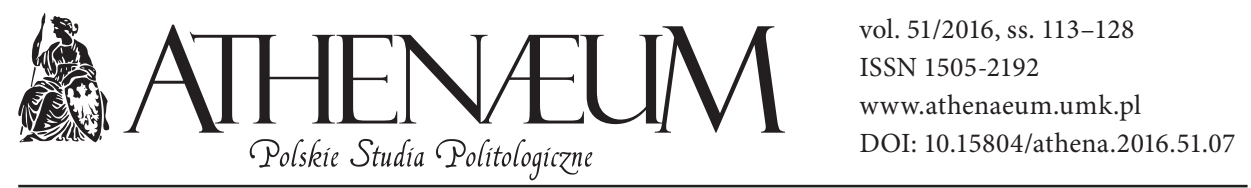

\title{
DYPLOMACJA SPORTOWA JAKO KATEGORIA NAUK O POLITYCE
}

\author{
SPORTS DIPLOMACY AS A CATEGORY OF POLITICAL SCIENCE
}

Michał Marcin Kobierecki*

\begin{abstract}
ABSTRAKT
Celem artykułu jest zbadanie pojęcia dyplomacja sportowa. Mimo że znaczenie sportu w dyplomacji wydaje się być dostrzegane i rozumiane przez badaczy w Polsce, zagadnienie to nie było jak dotąd szerzej analizowane. Jako że termin ten jest zazwyczaj uznawany za jeden z wymiarów dyplomacji publicznej, artykuł poświęcony jest także zbadaniu kwestii roli i miejsca sportu w jej ramach.

W treści artykułu przedstawiony został szereg sposobów rozumienia pojęcia dyplomacja sportowa prezentowanych przez różnych badaczy. Naukowcy rozumieją ten termin w sposób zróżnicowany, w szczególności jeżeli chodzi o jego zakres. W związku z tym $\mathrm{w}$ artykule podjęto próbę zaproponowania najbardziej adekwatnego sposobu rozumienia tego pojęcia.
\end{abstract}

Słowa kluczowe: Dyplomacja sportowa, dyplomacja publiczna, polityka sportu
The aim of the article is to investigate the term 'sports diplomacy'. Although the significance of sport in diplomacy seems to be recognized and understood by scholars in Poland, it has not been analysed in a deeper way so far. As the term is usually regarded as one of the dimensions of public diplomatic, the role and place of sport within public diplomacy is also analysed.

In the article, a number of ways of understanding sports diplomacy by various scholars will be introduced. Scientist tend to regard this term differently, especially in respect to its range. Therefore, an attempt to provide the most appropriate way of understanding sports diplomacy will be conducted.

Keywords: sports diplomacy, public diplomacy, politics on sport

* Uniwersytet Łódzki, Katedra Teorii Polityki i Myśli Politycznej. 


\section{WPROWADZENIE}

W październiku 2014 roku z inicjatywy Polskiego Komitetu Olimpijskiego we współpracy z Ministerstwem Spraw Zagranicznych RP oraz Ministerstwem Sportu i Turystyki RP odbyło się w Warszawie międzynarodowe sympozjum pod hasłem „Dyplomacja sportowa istotną płaszczyzną dyplomacji publicznej” (Polski Komitet Olimpijski, 2014). Obrady zakończyło sformułowanie pewnych wniosków i rekomendacji. Wśród nich na uwagę zasługuje „uznanie dyplomacji sportowej za niezwykle ważny element dyplomacji publicznej [...] sport może bowiem wspomóc wysiłki dyplomacji zmierzające do kształtowania pozytywnego wizerunku kraju i jego obywateli oraz promocji jako miejsca godnego odwiedzenia i bliższego poznania" (Polski Komitet Olimpijski, 2014, Wnioski i rekomendacje).

Upolitycznienie sportu czy szerzej - wzajemne przenikanie się sportu i polityki jest zagadnieniem cieszącym się coraz większym zrozumieniem wśród naukowców. Mimo że w naszym kraju badacze reprezentujący nauki społeczne, $\mathrm{w}$ tym nauki o polityce, dopiero od niedawna wykazali zainteresowanie tym zagadnieniem, to w ostatnim czasie pojawiło się szereg wartościowych badań w tym zakresie. Inaczej wygląda sytuacja, jeśli chodzi o dyplomację sportową zagadnienie niemal zupełnie niepodjęte, jeśli chodzi o naukę polską, dopiero zaś od niedawna rozpatrywane za granicą.

Celem artykułu będzie analiza znaczenia pojęcia dyplomacja sportowa, w szczególności zaś, nawiązując do przesłania wspomnianego sympozjum, usytuowania go w ramach szerszego pojęcia, jakim jest dyplomacja publiczna. Podjęta zostanie w związku z tym próba odpowiedzi na pytanie badawcze, czy dyplomację sportową można uznać za kategorię politologiczną. W artykule pojawią się ponadto odniesienia do miękkiej siły państwa, z którą w sposób ścisły powiązane jest pojęcie dyplomacji publicznej. Analiza oparta będzie na przeglądzie różnych ujęć dyplomacji sportowej w zagranicznej literaturze naukowej, gdyż jak wspomniano, w Polsce tematyka ta nie została jak dotąd szerzej podjęta. Do uchwycenia istoty tego pojęcia posłużą także ujęte skrótowo przykłady działań, które można określić jako dyplomacja sportowa. 


\section{DYPLOMACJA SPORTOWA - RÓŻNE KONOTACJE I INTERPRETACJE}

\subsection{Ujęcie wąskie}

Kiedy sport rozpatrywany jest w kategoriach dyplomatycznych, najczęściej przytaczanym przykładem jest tzw. dyplomacja pingpongowa pomiędzy Chińską Republiką Ludową a Stanami Zjednoczonymi. ChRL pozostawała w międzynarodowej izolacji w związku z konfliktem z popieraną przez kraje zachodnie Republiką Chińską (Tajwanem) oraz pogorszeniem stosunków z tzw. blokiem radzieckim. Dyplomacja pingpongowa doprowadziła do wizyty prezydenta USA Richarda Nixona w Pekinie w dniach 21-28 lutego 1972 roku. Swoistym wstępem do tego wydarzenia była wizyta dziewięciu amerykańskich tenisistów stołowych, czterech działaczy, dwóch osób towarzyszących i 10 dziennikarzy w Chinach w kwietniu 1971 roku. Chińczycy zaprosili amerykańskich sportowców do Pekinu kilka dni wcześniej, podczas odbywających się w Japonii mistrzostw świata w tenisie stołowym. Warto dodać, iż obydwa kraje od pewnego czasu poszukiwały możliwości zbliżenia. Od początku lat 70. podejmowano liczne próby dyplomacji tajnej zmierzającej do zaaranżowania spotkania polityków, obawiano się jednak tajwańskiego lobby w USA. Jednak już podczas wizyty amerykańskich tenisistów stołowych w Chinach Waszyngton ogłosił zniesienie trwającego od 22 lat embarga na handel z Chinami oraz szereg innych gestów (Xia, 2006). Nastąpił wówczas szybki rozwój wydarzeń i już w lipcu 1971 roku Sekretarz Stanu USA Henry Kissinger złożył pierwszą wizytę w Chinach, w październiku zaś kolejną, przygotowując późniejszą podróż prezydenta Nixona z lutego 1972 roku (Goldstein, Freeman, 1990). W związku z tym dyplomację pingpongową można określić jako narzędzie, które obie strony wykorzystały, aby ułatwić późniejsze podjęcie działań dyplomacji klasycznej, nie ryzykując ewentualną kompromitacją wizerunkową w przypadku fiaska inicjatywy.

Przykładów na podobne, instrumentalne wykorzystywanie sportu było znacznie więcej. Dość wspomnieć o kubańsko-amerykańskiej dyplomacji baseballowej (a także koszykarskiej) czy dyplomacji krykietowej pomiędzy Indiami a Pakistanem. Obejmowały one instrumentalne wykorzystanie uniwersalności i pokojowego charakteru sportu w celu nawiązania lub wzmożenia kontaktów dyplomatycznych w sytuacji oficjalnie wrogiego nastawienia poszczególnych państw. W okresie zimnej wojny podejmowane były także liczne próby pewnego zbliżenia pomiędzy Związkiem Radzieckim a Stanami Zjednoczonymi dzięki kontaktom sportowym - organizowano przykładowo dwustronne spotkania lek- 
koatletyczne (Turrini, 2001). Jak określił to amerykański badacz Andrew L. Johns (2014), sport „odzwierciedla wspólne zainteresowania dzielone przez ludzi na całym świecie oraz ma zdolność przekraczania granic politycznych, kulturalnych, społecznych, płciowych, religijnych i gospodarczych oraz zapewnia wspólne podstawy, [może więc być użyteczny w] budowaniu mostów pomiędzy rządami i narodami" (s. 3). O sporcie można ponadto powiedzieć, iż ze względu na swoją subtelność i plastyczność dodaje do repertuaru narzędzi polityki zagranicznej dodatkowe elementy (Houlihan, 2004).

Podobne do zaprezentowanego powyżej ujęcie przedstawił David Rowe (2011). Autor ten postrzega dyplomację sportową jako stosunkowo bezpieczny, łagodny sposób „nawiązywania przyjaźni” oraz zażegnywania konfliktów, jako jeden z przykładów podając wykorzystanie igrzysk olimpijskich do poprawy relacji pomiędzy Koreą Północną i Południową. Przykładowo podczas igrzysk olimpijskich w Sydney w 2000 roku obie reprezentacje maszerowały wspólnie podczas ceremonii otwarcia (Hong, 2011), a także rozważano rozegranie części konkurencji igrzysk olimpijskich w Seulu w 1988 roku na terytorium Korei Północnej (Guttmann, 2002). Podobny pogląd zaprezentował Jacquie L’Etang (2013), według którego sport wykorzystywany jest przez rządy w dyplomacji publicznej, aby zasygnalizować chęć zacieśnienia relacji. Niemniej stwierdzić trzeba, iż takie zawężające podejście do dyplomacji sportowej należy do mniejszości.

\subsection{Ujęcie szerokie}

Większość badaczy wyraża jednak zrozumienie dla poglądu, iż dyplomacja sportowa jest pojęciem znacznie szerszym, aczkolwiek w różnych ujęciach eksponowane są różne jego elementy. Anurag Saxena (2012) stwierdził np., iż dyplomacja sportowa to sytuacja, kiedy sport jest wykorzystywany jako narzędzie polityczne, aby poprawić lub czasem pogorszyć stosunki dyplomatyczne pomiędzy dwoma bytami. Autor ten najwyraźniej zalicza do kategorii dyplomacji sportowej nie tylko działania podobne do wspomnianej już dyplomacji pingpongowej, ale także obejmujące intencjonalne wykorzystanie sportu do podkreślenia niezadowolenia z polityki danego kraju. Może się to wiązać z bojkotem sportowym. Do najbardziej znanych należy ten dotyczący igrzysk olimpijskich w Moskwie w 1980 roku, z udziału w których w konsekwencji radzieckiej interwencji w Afganistanie zrezygnowało 56 państw na czele ze Stanami Zjednoczonymi (Lipoński, 2000), chociaż autorzy różnią się co do dokładnej liczby. Drugi z najbardziej znanych 
bojkotów sportowych miał miejsce cztery lata później i dotyczył igrzysk olimpijskich w Los Angeles w 1984 roku, kiedy to prawdopodobnie jako swoisty rewanż za bojkot igrzysk w Moskwie na zawodach nie pojawili się sportowcy z 15 państw (D’Agati, 2013), przede wszystkim komunistycznych. Oczywiście bojkotów sportowych o mniejszym lub większym zasięgu było w historii znacznie więcej, współcześnie natomiast często stosuje się bojkot polegający na rezygnacji z obecności na tego typu zawodach sportowych przez politycznych przedstawicieli poszczególnych państw.

Niezadowolenie z polityki takiego czy innego podmiotu można wyrażać także poprzez działania ukierunkowane na sportowe izolowanie kontestowanego kraju, jak miało to miejsce chociażby w odniesieniu do Republiki Południowej Afryki w okresie, gdy kraj ten prowadził politykę apartheidu, a także Izraela przykładowo sportowcy z tego kraju nie zostali wpuszczeni na terytorium Indonezji w 1963 roku, gdzie odbywały się Igrzyska Azjatyckie (Espy, 1981). Takie wykorzystanie sportu w celu potępienia konkretnego kraju niektórzy badacze określają jako negatywną dyplomację sportową (Houlihan 2004, Houlihan, 2002, Downes, 2014).

Podobne ujęcie prezentują także inni autorzy. Według Rui Santosa, Alexandre Mestre'a i Francisco de Megalhāesa (2011) dyplomacja sportowa obejmuje działania promujące pokój i współpracę, ale także jest narzędziem konfrontacji ideologicznej lub demonstracji siły i władzy. Podobną opinię prezentuje Ellis Cashmore (2000), a także Phillip D’Agati (2013), który jako istotny element dyplomacji sportowej wskazuje właśnie wykorzystywanie sportu do eksponowania niezgody pomiędzy narodami. Dyplomacja sportowa bywa przy tym określana jako „dodatek” do tradycyjnych praktyk dyplomatycznych państw, ukierunkowany m.in. na wzmacnianie rządowej pozycji, np. w odniesieniu do uznania dyplomatycznego państw lub niezadowolenia z zachowania krajów goszczących zawody sportowe (Beacom, 2004).

Wśród niektórych naukowców dominuje podejście, iż dyplomację sportową należy rozumieć co prawda zarówno w odniesieniu do budowania współpracy międzynarodowej, jak i eksponowania konfliktu, jednakże niemal wyłącznie w kontekście bezpośredniego, instrumentalnego wykorzystania przez rządy. Wg Martina Polley’a (2007) dyplomacja sportowa generalnie oznacza wykorzystywanie przez rządy sportu do wyrażania opinii odnośnie innych krajów, i tak bojkoty sportowe wyrażać mają niezadowolenie i potępienie. Tymczasem przykładem odwrotnym, zakładającym oświadczenie o normalizacji i łagodzeniu stosunków, miała być decyzja brytyjskiego rządu odnośnie promowania sporto- 
wych relacji z Niemcami w latach trzydziestych XX wieku. Autor ów stwierdził ponadto, iż dyplomacja sportowa była istotną cechą sportu już od początków XX wieku. W powyższym ujęciu dostrzec można przywiązanie do tradycyjnego rozumienia dyplomacji jako atrybutu państw. O ile dyplomacja sportowa jest oczywiście narzędziem i atrybutem rządów, to jednak szczególnie w dzisiejszych czasach zakres tego terminu wydaje się znacznie szerszy, obejmuje bowiem także aktywność szeregu aktorów niepaństwowych. Warto w tym miejscu dodać, iż aby dany przykład przenikania się sportu i polityki uznać za dyplomację sportową, powinien on mieć charakter intencjonalny, nie zaś spontaniczny, jak miało to miejsce chociażby w przypadku wojny futbolowej pomiędzy Salwadorem a Hondurasem w 1969 roku - bezpośrednią przyczyną jej wybuchu był właśnie mecz piłkarski (Kapuściński, 1976).

O konieczności szerszego rozumienia terminu dyplomacja sportowa świadczą także publikowane przez niektóre kraje informacje odnośnie jej prowadzenia. Przykładowo Ministerstwo Spraw Zagranicznych Korei Południowej w Białej Księdze Dyplomacji (2014) odnosiło się do tego zagadnienia, stwierdzając, iż dyplomacja sportowa jest „,narzędziem wzmocnienia bilateralnej i multilateralnej współpracy sportowej” oraz wspominając o rządowym zaangażowaniu w zdobywanie prawa organizacji zawodów sportowych, wspieraniu kandydatur Koreańczyków do zarządów organizacji sportowych czy pomocy w organizowaniu zagranicznych pokazów i turniejów w taekwondo. Szczególnie interesujące ujęcie tematu można znaleźć także w kontekście prowadzonej przez Departament Stanu USA dyplomacji amerykańskiej, w ramach której podjęto starania, aby połączyć sport z amerykańską działalnością dyplomatyczną (Johns, 2014). W Congressional Record (2003) w kontekście dyplomacji sportowej stwierdzono, co następuje: „Sekretarz otrzymał autoryzację, aby zwiększyć wysiłki, aby promować interesy amerykańskiej dyplomacji publicznej w spełniających warunki krajach oraz w innych poprzez dyplomację sportową" (s. 25790). We wspomnianym dokumencie wymieniono ponadto, jakie działania program ten może obejmować, mianowicie dwustronne wymiany ukierunkowane na szkolenie sportowców i drużyn, dwustronne wymiany ukierunkowane na pomoc krajom w tworzeniu i poprawie ich programów sportowych, zdrowotnych i edukacyjnych, pomoc organom zarządzającym sportem w Stanach Zjednoczonych we wzmacnianiu współpracy z ich odpowiednikami w innych krajach oraz wykorzystywanie amerykańskich zawodowych sportowców oraz innych znanych osobistości ze świata sportu we wspieraniu celów i działalności dyplomacji publicznej. Ujęcie to zalicza do kategorii dyplomacji sportowej dwa główne typy działań o charak- 
terze międzynarodowym. Po pierwsze jest to nawiązywanie szeroko pojętych, przede wszystkim dwustronnych kontaktów sportowych, skupionych głównie na wspieraniu szkolenia i rozwoju w dziedzinie sportu w partnerskich krajach. W praktyce obejmuje to przede wszystkim wysyłanie za granicę trenerów poszczególnych sportów, ekspertów lub zawodników na wspólne treningi. Drugie zagadnienie obejmuje wykorzystanie globalnej rozpoznawalności największych gwiazd sportu, które Departament Stanu zatrudnia do prowadzenia swoistej promocji USA. Dotychczas byli to m.in. tacy sportowcy, jak członek baseballowej galerii sław Cal Ripken, dwukrotna medalistka olimpijska i pięciokrotna mistrzyni świata w łyżwiarstwie figurowym Michelle Kwan, koszykarze występujący w lidze NBA Juwan Howard i Dikembe Mutombo czy koszykarka Nikki McCray (Johns, 2014). Ujęcie to nie obejmuje natomiast wprost zagadnienia „przełamywania politycznych izolacji”, do czego nawiązano wcześniej. Warto jednocześnie wspomnieć, iż w opisywanym rozumieniu dyplomacja sportowa została blisko powiązana $\mathrm{z}$ dyplomacją publiczną. Zagadnienie to stanie się przedmiotem rozważań w dalszej części artykułu.

Stuart Murray i Goeffrey Pigman (2014) podzielają pogląd, iż dyplomację sportową należałoby rozumieć w sposób szerszy. Badacze ci dokonali dogłębnej analizy znaczenia terminu dyplomacja sportowa, uznając zarazem, iż relacje pomiędzy międzynarodowym sportem a dyplomacją wydają się rozumiane, jednak niedostatecznie zbadane. Autorzy ci, tłumacząc pojęcie dyplomacji sportowej, wyróżnili dwie jej kategorie. Pierwsza dotyczy sytuacji, w których międzynarodowy sport jest wykorzystywany przez rządy jako instrument dyplomatyczny, druga natomiast została określona jako „międzynarodowy sport jako dyplomacja”. Obejmuje ona dyplomatyczną reprezentację, komunikację i negocjacje pomiędzy aktorami niepaństwowymi (a czasem także państwami), które mają miejsce na skutek toczącej się międzynarodowej rywalizacji sportowej. Przykładowo organizacje zarządzające sportem angażują się w negocjacje z państwami przypominające dyplomację odnośnie chociażby organizacji imprez sportowych, a ich przedstawiciele są często przyjmowani w poszczególnych krajach niczym dyplomaci. Badacze ci reprezentują zatem rozszerzające rozumienie pojęcia dyplomacja sportowa, do którego w dużym stopniu przychyla się autor niniejszego artykułu. Trudno bowiem zgodzić się z realistycznym podejściem, iż dyplomacja sportowa stanowi domenę jedynie rządów państw, które wykorzystują sport instrumentalnie do preferowania własnych interesów na arenie międzynarodowej. Jest to oczywiście wymiar dyplomacji sportowej najsilniej uobecniony w świadomości zbiorowej, a także najistotniejszy z perspektywy 
politologicznej analizy tego zagadnienia. Niemniej, w globalizującym się świecie dostrzec można wszechstronny wzrost znaczenia aktorów niepaństwowych w stosunkach międzynarodowych. Tendencja ta dotyczy oczywiście także światowego sportu.

Jak widać, istnieją różne sposoby rozumienia dyplomacji sportowej, zarówno zawężające, jak i szersze. Najwęższe oznacza oczywiście postrzeganie jej przez pryzmat najbardziej znanego przykładu - dyplomacji pingpongowej, a zatem rozumienie jej jako narzędzia budowania zbliżenia pomiędzy krajami w sytuacji, gdy nawiązanie kontaktów przez tradycyjnych dyplomatów jest z różnych względów niemożliwe. Zdecydowanie dominuje jednak rozumienie szersze - zakładające, iż dyplomacja sportowa obejmuje także wykorzystywanie sportu w eksponowaniu negatywnych relacji w stosunkach międzynarodowych. I w tym kontekście nie ma jednak zgodności, ponieważ część autorów rozumie dyplomację sportową jako atrybut wyłącznie rządów państw, które w sposób instrumentalny wykorzystują sport w kontekście aktualnych potrzeb - czy to do budowania zgody, czy eksponowania niezgody międzynarodowej. W tym kontekście dyplomację sportową można określić jako pewien instrument dyplomacji. Inni z kolei wiążą oczywiście dyplomację sportową z działalnością państwa, jednak zwracają uwagę także na inny aspekt tego działania, to jest na aktywność poprzez innych aktorów, np. organizacje czy kluby sportowe. W obu przypadkach adresatem działań dyplomacji sportowej są oczywiście rządy państw, a także ich społeczeństwa. Wreszcie, w najbardziej rozszerzającym rozumieniu dyplomacji sportowej zwraca się ponadto uwagę na „świat sportu jako arenę dyplomatyczną”, a organizacje sportowe jako jej kluczowe podmioty.

\section{SPORT W KONTEKŚCIE DYPLOMACJI PUBLICZNEJ}

Jak stwierdzono wcześniej, istnieje dość silna tendencja do określania dyplomacji sportowej jako elementu dyplomacji publicznej. Nawiązania do wykorzystania sportu w jej działaniach można także znaleźć w wielu opracowaniach poświęconych temu zagadnieniu. Beata Ociepka (2013) stwierdziła na przykład, iż sport ma istotną rolę w dyplomacji publicznej w związku z możliwością wykorzystania go do budowania międzynarodowej pozycji państwa, jednak nie rozwija szerzej zagadnienia dyplomacji sportowej. Takie budowanie wizerunku polegać może przykładowo na organizacji imprez sportowych, w szczególności tzw. mega-eventów, czyli igrzysk olimpijskich i mistrzostw świata i Europy w piłce 
nożnej, bowiem dzięki wielkiej popularności są one śledzone przez ludzi na całym świecie za pośrednictwem mediów, a także przyciągają turystów. Inne przykłady takiego wykorzystania sportu to osiąganie dobrych wyników w sporcie - w ten sposób pozycję międzynarodową budowały niegdyś Niemcy Wschodnie, sportowa pomoc rozwojowa, a więc wspieranie rozwoju sportu w krajach biedniejszych przez kraje bogatsze, takie jak Stany Zjednoczone czy Norwegia, udział w międzynarodowej rywalizacji sportowej - w przypadku państw małych lub bez pełnego uznania, organizowanie bilateralnych spotkań sportowych itp. W celu pełnego zrozumienia miejsca dyplomacji sportowej w ramach dyplomacji publicznej niezbędne jest wyjaśnienie istoty pojęcia dyplomacja publiczna.

James Pamment (2013) określił dyplomację publiczną jako komunikację polityki międzynarodowego aktora do obywateli innych państw, przy czym przez obywateli należy rozumieć reprezentantów społeczeństwa obywatelskiego, organizacje pozarządowe, przedsiębiorstwa transnarodowe, dziennikarzy i instytucje medialne, specjalistów różnych dziedzin przemysłu, polityki i kultury oraz opinii publicznej. Komunikacja taka jest prowadzona przez ministrów spraw zagranicznych, organizacje pozarządowe i organizacje społeczeństwa obywatelskiego za pośrednictwem takich narzędzi, jak: komunikaty medialne, konferencje i eventy, wspólne przedsięwzięcia oraz wymianę kultury, personelu i studentów. Działania te mają realizować założenie, iż możliwe jest wpływanie na relacje między rządami poprzez angażowanie obywateli i ich grup, których opinie, wartości, aktywności i zainteresowania mogą pomóc w dostosowaniu podejścia drugiego rządu. Ujęcie to wydaje się trafnie odzwierciedlać istotę dyplomacji publicznej, która polega na takim nawiązywaniu kontaktów z państwem, w stosunku do którego prowadzone są jej działania, aby przekonać jego obywateli o pozytywnych cechach własnych (kraju i społeczeństwa), co w dalszej kolejności ma wpłynąć na oficjalną politykę jego rządu.

Podobne rozumienie dyplomacji publicznej można znaleźć także u innych naukowców, a także w dokumentach państwowych. Amerykański Departament Stanu określa dyplomację publiczną jako informowanie zagranicznej opinii publicznej oraz zdobywanie poparcia dla celów amerykańskiej (w tym przypadku) polityki zagranicznej (Waller, 2007). Dyplomacja publiczna bywa też określana jako transparentne środki, poprzez które suwerenny kraj komunikuje się ze społecznościami innych krajów, mając na celu informowanie oraz wpływanie na zagranicznych odbiorców w celu promowania interesów narodowych i wspierania realizacji celów polityki zagranicznej (House of Commons Foreign Affairs Committee, 2012).Wg B. Ociepki (2008) dyplomacja publiczna to jedna 
z form komunikowania politycznego w wymiarze międzynarodowym, która jest skierowana do szerszego grona odbiorców niż dyplomacja klasyczna. Jej podmiotami są oczywiście rządy państw, ale także organizacje pozarządowe oraz inni uczestnicy stosunków międzynarodowych, których działalność wpływa na wizerunek państwa lub społeczeństwa. Kwestie wizerunkowe nabierają kluczowego znaczenia, jeśli chodzi o dyplomację publiczną.

Zagadnienie dyplomacji publicznej jest ściśle powiązane z pojęciem miękkiej siły. Bywa ona bowiem także definiowana jako narzędzie zarządzania zasobami miękkiej siły, ukierunkowane na zwiększanie miękkiego potencjału państwa oraz koordynację wszystkich zasobów siły miękkiej oraz wykorzystania zasobów siły gospodarczej (Ociepka, 2013), mimo że gospodarka z założenia zaliczana jest raczej do siły twardej. Pojęcie soft power bezpośrednio wiązane jest $\mathrm{z}$ osobą Josepha Nye’a (2004), który stwierdził, iż państwo może niekiedy zrealizować swoje cele bez odwoływania się do gróźb czy zapłat, ale ponieważ inne kraje będą chciały iść jego śladem - podziwiając wartości, jakie reprezentuje, naśladując jego przykład, aspirując do jego poziomu dobrobytu i otwartości. Miękka siła polega zatem wg Nye’a na sprawianiu, aby, inni chcieli rozstrzygnięć takich jak my” (s. 5).

Istnieje szereg elementów określanych mianem zasobów miękkiej siły, które brane są pod uwagę w licznych próbach sporządzenia swoistych rankingów państw w tej dziedzinie. Należą do nich migracje, turystyka, sport, kultura, obecność danego kraju w mediach, technologia, nauka, edukacja, pomoc rozwojowa danego kraju, reżim, polityka zagraniczna itp. (Ociepka, 2013, McClory, 2012). Miękka siła jest więc siłą przyciągania związaną z wyrosłą z szeregu niematerialnych zasobów atrakcyjnością danego państwa.

Warto wskazać na różnicę pomiędzy dyplomacją publiczną a propagandą. Niekiedy bowiem dochodzi do utożsamiania tych dwóch pojęć, czasem także z public relations. B. Ociepka (2013) wskazuje, iż różnica pomiędzy dyplomacją publiczną a propagandą polega na „symetrii bądź jej braku” - zgodnie z tym ujęciem dyplomacja publiczna obejmuje działania symetryczne, biorące pod uwagę interesy odbiorców, podczas gdy propaganda opatrzona jest przymusem państwowym i obejmuje realizację wyłącznie interesów nadawcy oraz zastosowanie metod manipulacyjnych (s. 89, 91). Pojawiają się jednak także poglądy, iż dyplomacja publiczna jest niczym innym jak kontynuacją dawniej prowadzonej propagandy międzynarodowej, w związku ze zmieniającymi się realiami środowiska międzynarodowego oraz pejoratywnym rozumieniem słowa „propaganda” (House of Commons Foreign Affairs Committee, 2012). Należałoby chyba jednak zgodzić się z B. Ociepką, iż istnieją silnie zarysowane różnice jakościowe 
pomiędzy działaniami propagandowymi a tymi z zakresu dyplomacji publicznej, jednak czasami granica ta jest płynna i trudna do jednoznacznego określenia. Istnieją bowiem aspekty instrumentalnego wykorzystania sportu przez chociażby Związek Radziecki, które z całą pewnością można by zaklasyfikować jako dyplomacja publiczna.

Państwem o szczególnych doświadczeniach, jeśli chodzi o prowadzenie dyplomacji publicznej, są Stany Zjednoczone, których rząd podjął wysiłki ukierunkowane na wpływanie na światową opinię publiczną już na początku lat 40. XX wieku. W 1953 roku w USA stworzono stosowną komórkę organizacyjną - działającą aż do 1999 roku Agencję Informacyjną Stanów Zjednoczonych (United States Information Agency, w skrócie USIA). USIA odpowiedzialna była za formułowanie i egzekwowanie strategii Stanów Zjednoczonych, jeśli chodzi o zagraniczne działania informacyjne oraz kulturalne (Dizard Jr., 2004). Oczywiście agencja działała zgodnie z wytycznymi Departamentu Stanu, który przejął jej funkcje związane z dyplomacją publiczną po jej likwidacji - obecnie są one realizowane przez Podsekretarza ds. Dyplomacji Publicznej i Spraw Publicznych (United States Government Accountability Office, 2009).

Istnieje szereg charakterystycznych praktyk podejmowanych w ramach dyplomacji publicznej. Niektórzy autorzy wyróżniają jej swoiste typy. Obok analizowanej dyplomacji sportowej wskazuje się chociażby na dyplomację obywatelską, która jest prowadzona przez „zwykłe osoby” - studentów, nauczycieli, sportowców, artystów, ludzi biznesu, podróżników czy turystów. Osoby te angażują się we wzajemnie korzystny dialog z resztą świata (Smith, 2009). Bywa ona także określana jako dyplomacja drugiego toru. Praktyczny wymiar tego typu dyplomacji wiąże się z wszelkiego rodzaju wymianami. Najbardziej typowym przykładem jest w tym przypadku wymiana studencka. Warto dodać, iż w pewnych okolicznościach dyplomacja obywatelska odbywa się także w ramach dyplomacji sportowej - szczególnie gdy dochodzi do różnego rodzaju zagranicznych szkoleń dla sportowców. W kontekście tak pojętej dyplomacji publicznej rola państwa obejmuje przede wszystkim tworzenie i zarządzanie różnego rodzaju programami wymiany.

Inną popularną formą dyplomacji publicznej jest tzw. dyplomacja kulturalna. Termin ten można rozumieć jako działanie rządów w sferze międzynarodowych stosunków kulturalnych. Dotyczy to szerokiego rozumienia kultury, zatem obejmującego zarówno tzw. kulturę wysoką utożsamianą ze sztuką, jak i „wszystko co nie jest naturą". Działanie w ramach dyplomacji kulturalnej obejmuje więc szerzenie wiedzy na temat kultury, osiągnięć cywilizacyjnych i historii danego kraju (Mickie- 
wicz, 2008). O dyplomacji kulturalnej twierdzi się niekiedy, że poprzedziła dyplomację publiczną - była bowiem istotnym elementem działalności krajów podczas zimnej wojny. Programy wymiany kulturalnej tego okresu koncentrowały się na wystawach i wymianie studentów. W ramach dyplomacji kulturalnej wskazuje się także niekiedy na dyplomację historyczną ukierunkowaną na przedstawianie pożądanego (prawdziwego wg nadawcy) obrazu historii (Ociepka, 2013).

W powyższych rozważaniach nad dyplomacją publiczną istotny wydaje się wątek związany z zaangażowaniem państwa w jej prowadzenie lub - jak to wcześniej ujęto - w jej koordynację. Zrozumiałe jest bowiem, iż dyplomacja publiczna często prowadzona jest nie bezpośrednio przez władze takiego czy innego kraju, ale także przez szereg innych aktorów, np. firmy działające w skali ponadnarodowej, organizacje pozarządowe czy samych obywateli. W związku z tym może pojawić się wątpliwość, czy spontaniczne i nieskoordynowane działania tych aktorów, które mimo wszystko prowadzą do zmiany wizerunku państwa, które reprezentują, lub też do realizacji innych celów jego polityki zagranicznej, także należałoby zaliczyć do dyplomacji publicznej, czy też są to już działania wykraczające poza jej spectrum? Jak się zdaje, dyplomacja publiczna powinna być jednak prowadzona w sposób planowany i skoordynowany, za co powinny odpowiadać stosowne departamenty, np. Ministerstwa Spraw Zagranicznych. Z drugiej jednak strony istnieje wiele przejawów dyplomacji publicznej, które trudno określić jako skoordynowane. Przykładowo, ocenia się, że dyplomacja publiczna Kanady, kraju, który często wykorzystywał w tym celu także sport, przez długi okres obejmowała raczej improwizację niż skoordynowane działania oraz że nie udało się stworzyć ogólnokrajowego podejścia do zarządzania międzynarodowym wizerunkiem Kanady (Potter, 2009). Zatem należałoby stwierdzić, iż pożądana dyplomacja publiczna powinna być oczywiście skoordynowana przez władze państwowe i taki też powinien być ich cel, jeśli chodzi o zarządzanie brandem kraju czy też zasobami miękkiej siły. $Z$ drugiej jednak strony działania podejmowane przez aktorów niepaństwowych, np. firmy międzynarodowe pochodzące z danego kraju czy kluby sportowe, jeśli podejmowane są samodzielnie i przynoszą korzyść wizerunkową danemu krajowi, to także należałoby je chyba zaliczyć do dyplomacji publicznej. Rolą państwa jest w tym przypadku umiejętne ich wykorzystanie, nawet jeśli samo nie było ich inicjatorem.

Jak wspomniano, określanie dyplomacji sportowej jako swoistej subkategorii dyplomacji publicznej jest stosunkowo powszechne, mimo że niekiedy jest to ujmowane jako „sport w dyplomacji publicznej”. Niektórzy autorzy wskazują nawet, iż wzajemne oddziaływanie sportu i polityki zalicza się do sfery dyplo- 
macji publicznej w szerokim jej ujęciu (Johns, 2014), chociaż takie rozumienie wydaje się jednak zbyt szerokie. Trzeba się jednak zgodzić z opinią, iż sport jako narzędzie dyplomacji publicznej nabierał w ostatnim czasie dużego znaczenia, chociażby w związku ewolucją jej celów w postzimnowojennym, globalnym świecie (Black, Peacock, 2013).

Pogląd zakładający, że dyplomacja sportowa to część dyplomacji publicznej, jest prezentowany przez szereg badaczy, i to niezależnie od tego, czy przyjmują zawężające, czy też szersze rozumienie tego terminu. Cytowany wcześniej J. L'Etang (2013) stwierdził, iż dyplomacja sportowa to część dyplomacji publicznej, która obejmuje rozwój komunikacji oraz nation-branding. W ujęciu tym widać zatem bezpośrednie odniesienie do wizerunku międzynarodowego państwa, co pokrywa się z opisanym wcześniej rozumieniem dyplomacji publicznej jako narzędzia eksponowania miękkich zasobów siły danego państwa. Istotne jest także nawiązanie do komunikacji, dyplomacja sportowa jest bowiem uważana za jedną z form komunikowania międzynarodowego. W tym kontekście poprzez dyplomację sportową państwo może kierować do innego kraju stosowny komunikat, np. o chęci zacieśnienia relacji lub o krytyce jego polityki. S. Murray i G. Pigman (2014), opisując dyplomację sportową, wyróżnili szereg jej ujęć, m.in. właśnie jako część dyplomacji publicznej - w tym kontekście jako jej przykłady autorzy ci podali zatrudnianie sportowców w celu wzmacniania komunikatów dyplomatycznych, a także wykorzystywanie w tym celu imprez sportowych oraz niekiedy uczestniczenie w wydarzeniach sportowych.

Miejsce dyplomacji sportowej w ramach dyplomacji publicznej dostrzegł Evan Potter (2009) w swojej analizie dotyczącej dyplomacji publicznej Kanady. Autor ów stwierdził wręcz, iż to poprzez sport nastąpił ogólny rozwój dyplomacji publicznej w tym kraju, a także określił go jako „unikalny instrument kanadyjskiej dyplomacji publicznej” (s. 90). Ów autor przytoczył szereg przykładów na kanadyjską dyplomację sportową w ramach dyplomacji publicznej - najstarszy z nich jeszcze z XIX wieku, kiedy kanadyjska drużyna lacrosse odbyła tournée po Wielkiej Brytanii, mając na celu zachęcanie do osadnictwa w zachodniej Kanadzie. Inne przykłady dotyczą promocji prestiżu i rozpoznawalności kraju poprzez dobre wyniki w międzynarodowym sporcie (konieczność taką już na początku zimnej wojny mieli zgłaszać kanadyjscy ambasadorowie na całym świecie), a także dyplomacji hokejowej, w ramach której poprzez spotkania sportowe miano łagodzić napięcia między Kanadą a innymi państwami, w szczególności komunistycznymi, zgodnie z założeniem, iż to właśnie z hokejem na lodzie często kojarzony jest ten kraj i warto jest ten fakt wykorzystać. 


\section{KONKLUZJE}

W niniejszym artykule podjęto próbę przeanalizowania pojęcia dyplomacja sportowa. Jak wielokrotnie wspominano, jest to termin często zaliczany do szerszej kategorii dyplomacji publicznej. Analiza różnych ujęć prezentowanych przez naukowców badających problematykę dyplomacji sportowej i publicznej pozwoliła na sformułowanie konstatacji, iż istnieje cały szereg sposobów rozumienia dyplomacji sportowej, obejmujących różne zakresy znaczeniowe tego pojęcia. Niektórzy autorzy rozumieją bowiem dyplomację sportową jedynie z perspektywy wykorzystywania przez państwa kontaktów sportowych w celu realizacji konkretnego interesu politycznego, np. „budowania mostów” pomiędzy wrogimi sobie krajami. Z kolei inni naukowcy prezentują szersze rozumienie tej kategorii, uwzględniające także takie jej cele, jak budowanie ogólnego wizerunku danego państwa na zewnątrz. Autor niniejszego artykuły przychyla się do właśnie takiego rozumienia dyplomacji sportowej.

W odniesieniu do dyplomacji sportowej jako części dyplomacji publicznej pojawiła się wątpliwość odnośnie nieskoordynowanych działań, jakie są podejmowane niekiedy przez aktorów niepaństwowych, jak na przykład kluby czy krajowe federacje sportowe. Stwierdzono w związku z tym, iż nawet jeśli ich inicjatywy podejmowane są samodzielne i nie są w pełni koordynowane przez władze państwowe, to jeśli przynoszą korzyść wizerunkową danemu krajowi, to także należałoby je uznać za dyplomację sportową.

Biorąc pod uwagę powyższe konstatacje, uprawnione wydaje się stwierdzenie, iż dyplomację sportową można uznać za kategorię nauk o polityce. Zagadnienie to szczególnie silnie wiąże się z takimi subdyscyplinami, jak komunikowanie polityczne czy marketing polityczny. Istnieje bardzo wiele przejawów dyplomacji sportowej, zarówno historycznych, jak i współczesnych, które warte są zbadania z perspektywy politologicznej. Obejmują one chociażby nawiązywanie kontaktów sportowych w celu preferowania zbliżenia międzynarodowego, bojkotowanie imprez sportowych jako środek komunikowania na zewnątrz niezadowolenia z polityki prowadzonej przez takie czy inne państwo, organizowanie wielkich imprez sportowych w celu kreowania międzynarodowego brandu kraju gospodarza i wiele innych. Tak szerokie i zdaniem autora niniejszego artykułu istotne pole badawcze nie powinno zatem zostać pominięte $\mathrm{w}$ badaniach politologicznych. 
Bibliografia:

Beacom, A. (2004). A changing discourse? British diplomacy and the Olympic Movement. W: R. Levermore, A. Budd (red.). Sport and International Relations. An Emerging Relationship (s. 93-111). London: Routledge.

Black, D., Peacock, B. (2013). Sport and Diplomacy. W: A.F. Cooper, J. Heine, R. Thakur (red.). The Oxford Handbook of Modern Diplomacy (s. 708-728). Oxford: Oxford University Press.

Cashmore, E. (2000). Sports Culture. An A-Z Guide. London: Routledge.

D'Agati, P.A. (2013). The Cold War and the 1984 Olympic Games. A Soviet-American Surrogate War. New York: Palgrave.

Dizard Jr., W.P. (2004). Inventing Public Diplomacy. The Story of the U.S. Information Agency. Boulder: Lynne Rienner Pub.

Downes, A.D. (2014). Forging Africa-Caribbean Solidarity within the Commonwealth? Sport and Diplomacy during the Anti-Apartheid Campaign. W: H.L. Dichter, A.L. Johns (red.). Diplomatic Games. Sport, stagecraft, and international relations since 1945 (s.117-150). Lexington: University Press of Kentucky.

Espy, R. (1981). The Politics of the Olympic Games. With Epilogue, 1976-1980. Berkeley: University of California Press.

Goldstein, J.S., Freeman, J.R. (1990). Three-Way Street. Strategic Reciprocity in World Politics. Chicago: University of Chicago Press.

Guttmann, A. (2002). The Olympics. A History of Modern Games. Chicago: University of Illinois Press.

Hong, F. (2011). Epilogue: Branding China: The Beijing Olympics and Beyond. W: J.A. Mangan, F. Hong (red.). Post Beijing 2008: Geopolitics, Sport and the Pacific Rim (s. 310-318). London: Routledge.

Houlihan, B. (2002). Political involvement in sport, physical education and recreation. W: A. Laker (red.). The Sociology of Sport and Physical Education. An Introductory Reader (s. 190-210). London: Routledge.

Houlihan, B. (2004). Politics and Sport. W: J. Coakley, E. Dunning (red.). Handbook of Sports Studies (s. 213-227). London: SAGE.

House of Commons Foreign Affairs Committee (2012). FCO Public Diplomacy: The Olympic and Paraolympic Games 2012. Second Report of Session 2010-11. London: The Stationery Office Limited.

Johns, A.L. (2014). Introduction. Competing in the Global Arena: Sport and Foreign Relations since 1945. W: H.L. Dichter, A.L. Johns (red.). Diplomatic Games. Sport, stagecraft, and international relations since 1945 (s. 1-18). Lexington: University Press of Kentucky.

Kapuściński, R. (1976). Wojna futbolowa. Warszawa: Agora.

L'Etang, J. (2013). Sports Public Relations. Los Angeles: SAGE.

Lipoński, W. (2000). Olimpizm dla każdego, Poznań: Wydawnictwo AWF Poznań.

McClory, J. (2012). The New Persuaders III. A 2012 Global Ranking of Soft Power. London: Institute for Government. 
Mickiewicz, M. (2008). Polska dyplomacja kulturalna. W: B. Ociepka (red.). Dyplomacja publiczna (s. 115-146). Wrocław: Wydawnictwo Uniwersytetu Wrocławskiego.

Ministry of Foreign Affairs, Republic of Korea (2014). Diplomatic White Paper 2014.

Murray, S., Pigman, G.A. (2014). Mapping the relationship between international sport and diplomacy. Sport in Society, 17(9), 1095-1097.

Nye, J.S. (2004). Soft Power. The Means to Success in World Politics. New York: Public Affairs.

Ociepka, B. (2008). Dyplomacja publiczna jako forma komunikowania międzynarodowego. W: B. Ociepka (red.). Dyplomacja publiczna (s. 11-36). Wrocław: Wydawnictwo Uniwersytetu Wrocławskiego.

Ociepka, B. (2013). Miękka siła i dyplomacja publiczna Polski. Warszawa: Scholar.

Pamment, J. (2013). New Public Diplomacy in the 21 $1^{\text {st }}$ Century. A Comparative study of policy and practice. Abingdon: Routledge.

Polley, M. (2007). Sports History. A Practical Guide. New York: Palgrave Macmillan.

Polski Komitet Olimpijski (2014). O sporcie i dyplomacji. Pobrane z: http://www.olimpijski.pl/pl/aktualnosci,89/909,o-sporcie-i-dyplomacjio-sporcie-i-dyplomacji.html.

Polski Komitet Olimpijski (2014). Wnioski i rekomendacje, Pobrane z: http://www. olimpijski.pl/Media/files/WNIOSKI_I_REKOMENDACJE_v2.pdf.

Potter, E.H. (2009). Branding Canada. Projecting Canada's Soft Power through Public Diplomacy. Montreal: McGill-Queens University Press.

Rowe, D. (2011). Global Media Sport. Flows, Forms and Futures. London: Bloomsbury Academic.

Santos, R.B., Mestre, A.M., de Megalhāesa, F.R. (2011). Sports Law in Portugal. Alphen aan den Rijn: Wolters Kluwer.

Saxena, A. (2012). The Sociology of Sport and Physical Education. New Delhi: Sports Publication.

Smith, A.A. (2009). Comparative Diplomacy. The Impact of the Future Leaders Exchange Programs. Ann Arbor: ProQuest.

Turrini, J.M. (2001). "It Was Communism Versus the Free World”: The USA USSR Dual Track Meet Series and the Development of Track and Field in the United States, 1958-1985. Journal of Sport History, Vol. 28, Nr. 3, 472-471.

United States Government Accountability Office (2009). U.S. Public Diplomacy. Key Issues for Congressional Oversight. Raport to Congressional Committees. Washington: GAO.

United States of America Congressional Record. Proceedings and Debates of the $108^{\text {th }}$ Congress First Session. Vol. 149 - Part 19. October 24 to November 4. 2003. Washington: United States Government Printing Office.

Waller, J.M. (red.). (2007). The Public Diplomacy Reader. Washington: Lulu.com.

Xia, Y. (2006). Negotiating with the Enemy. U.S. - China Talks during the Cold War, 1949-1972. Bloomington: Indiana University Press. 